\title{
Global Congresses and Global WAE Crises
}

John Carman, University of Birmingham, Birmingham, UK E-mail: j.carman@bham.ac.uk

Kathryn Weedman Arthur, University of South Florida, Saint Petersburg, USA E-mail: kjarthur@usf.edu

Published online: 16 November 2021

This Editorial is being written shortly after one WAC meeting-an Intercongress held virtually in early September 2021-and before another, a full WAC Congress to be hybrid in nature and planned for July 2022; and as it is written in early November world leaders have gathered in Glasgow, UK, for the UN Climate Change Conference called COP26. As the world still reels from the ongoing impact of Covid 19, we have all also experienced the growing consequences of climate change: increasing numbers and ferocity of storms causing damage and leading to floods in a number of countries, raging forest fires elsewhere, and temperatures in the arctic reaching an unprecedented $20^{\circ} \mathrm{C}\left(68^{\circ} \mathrm{F}\right)$. None of us are immune from its consequences.

\section{Climate Change}

COP26 is widely regarded as the world's last chance to avert a rise in global temperatures beyond $1.5^{\circ} \mathrm{C}$, which places a heavy responsibility on those able to make the necessary commitments to change in energy use and production throughout the world. It is therefore to be regretted that the leaders of some of the world's heaviest producers of greenhouse gases-especially China, as well as Russia-are not attending. We nonetheless wish the conference-the results of which will be known before the publication of his Editorial-well in its endeavours. We do so in particular because those communities for which we at Archaeologies and members of the World Archaeological Congress more widely have a special concern-the Indigenous, the subaltern and populations beyond the metropolitan centres of wealth-are those most at risk from change caused by rising temperatures and the concomitant increased energy in global weather systems, which causes storms and desertification.

We are not aware of any archaeologists who will contribute directly to discussions at COP26 but there are other events involving archaeologists taking place alongside, including lecture series on issues of sustainability by archaeologists at Glasgow, in London and in the Orkney Islands. Sustain- 
ability was a significant theme at WAC-8 in Kyoto in 2016 (Editorial Archaeologies, 2016; Howard and Trelka, 2016), and we published specifically on educating in archaeology on that topic in the same issue (Carman, 2016). It did not arise directly at the Intercongress in 2020, and no specific theme on Sustainability is planned for 2022: we nonetheless expect it to appear in various guises in 2022, especially in relation to issues of environmental change and engagement with communities, both of which concerns are reflected in WAC-9 themes.

Despite its absence at the Intercongress, archaeologists are nonetheless well placed to comment on climate change in the past and the present. As a single example, we can cite the work on 'Doggerland', Europe's lost country as the seas rose after the last Ice Age and formed what is now the North Sea between Britain and mainland Europe (Gaffney, Thomson and Fitch, 2007): as inundation proceeded the population was forced to move to less desirable environments, which is something populations may be forced to do later this century. Our own journal has a record of contributions to the wider debate about climate change: a search of the term reveals 63 references since the journal was founded and no fewer than 207 for 'environment'. There is perhaps some small comfort in knowing about environmental change in the past: that humanity has been through similar experiences before and has nonetheless survived as a species (although as we know, so has the polar bear). But there is also a warning: past adaptations-especially the emergence of agriculture, the development of urban centres, and technological advances especially over the past two centuries-are the things now causing the very changes that threaten the world and its fragile ecologies.

The most recent references in Archaeologies to environment and climate change are in our April 2021 Special Issue on 'Archaeology as a Public Good' guest edited by Stan Green and his colleagues. This points to the contribution archaeologists make to the contemporary world: our work is not all about lost pasts. In particular, there is a growing concern for the effects of climate change on archaeological resources: desertification in some areas and increasing rainfall and sea-level rise in others all threaten the material we investigate and the heritages and environments that people value (e.g. Howard, 2013). And as suggested above, many archaeologists work with and for the communities most likely to suffer the worst harm if climate change goes unchecked, but who are also those least able to make changes to their lives to ameliorate or reduce catastrophic effects.

The significance of climate change for archaeologists is recognised especially in the theme for upcoming WAC-9 on 'Climates of Change and Environmental Pasts'. We look forward to seeing the sessions contained in 
the theme and indeed individual contributions to those sessions and any outcomes they provide.

\section{This Issue}

This issue is (like the last) again shorter than we would like, containing only four substantive contributions. We suspect, among other factors, the ongoing consequences of Covid, which place heavier burdens on all scholars and thereby restrict the time that they can spend on publications and indeed reviewing others' work. Nonetheless, the four articles we present this month cover a large portion of the globe and especially areas in the global South less represented in the international literature: two from Eastern Sub-Saharan Africa, one from Southern Asia and another from South America. Two concern communities, in East Africa and South America, respectively, and two are ritual site-focused, one in Bhutan and the other in Ethiopia. Authors in turn are based in institutions in the USA, Colombia, Bhutan and Ethiopia.

Chapurukha Kusimba and Jonathan Walz take a historical perspective on Swahili identity as attested by scholars, especially archaeologists. They emphasise in particular the effect of colonial attitudes on constructions of African pasts and the way this reduces the Indigenous African cultures to the recipients of influence from outside, reducing their own agency. They point to the significance of the recent emergence of African archaeologists in studying their own pasts to redress this imbalance.

Equally political, Wilhelm Londono addresses the involvement of archaeology in Indigenous social movements in three cases in South America. Carefully distinguishing the decolonisation of archaeology from Indigenous archaeology and community archaeology, both of which are different, he points to repatriation processes established by local communities as a way forward towards decolonisation.

Jigme Thinley, Chimi Chimi and Nimesh Chettri assess the cultural significance of a Buddhist monastery in Bhutan in terms of its spiritual and special attributes. Primarily an exercise in cultural heritage management, the article also provides a solid basis on which to assess the value of such places in the changing context of Bhutanese urbanisation which will have resonances for those working elsewhere.

Tesfaye Tsegaye uses a study of newly-discovered prehistoric rock art in Ethiopia to highlight the difficulties of conducting archaeological research in the country, an issue that also affects other countries in Africa and elsewhere. The article calls for a more concerted effort at international support and efforts to involve local communities, while also indicating what these will involve. 
We commend the articles to you.

And as the holiday seasons approach, we wish all our readers health and happiness and all the best for the New Year 2022.

John and Kathy.

\section{References}

Carman, J. (2016). Educating for sustainability in archaeology. Archaeologies, 12(2), $133-152$.

Editorial Archaeologies. (2016). Forward to kyoto! Archaeologies, 12(2), 129-132.

Gaffney, V., Thomson, K., \& Fitch, S. (Eds.). (2007). Mapping doggerland: The mesolithic landscapes of the Southern North sea. Archaeopress.

Howard, A. J. (2013). Managing global heritage in the face of future climate change: The importance of understanding geological and geomorphological processes and hazards. International Journal of Heritage Studies, 19(7), 632-658.

Howard, S., \& Trelka, M. (2016). Personal, professional and academic journeys to WAC 8. Archaeologies, 12(2), 153-162.

Publisher's Note Springer Nature remains neutral with regard to jurisdictional claims in published maps and institutional affiliations. 